\title{
EXTENSIVE LISTENING AND VIEWING IN ELT
}

\author{
Francisca M. Ivone ${ }^{a}$, Willy A Renandya ${ }^{b}$ \\ ( ${ }^{a}$ francisca.maria.fs@um.ac.id) \\ Universitas Negeri Malang, Indonesia \\ Jl. Semarang 5 Malang, East Java, Indonesia, 65211 \\ ( ${ }^{b}$ willy.renandya@nie.edu.sg) \\ National Institute of Education, Nanyang Technological University \\ 50 Nanyang Ave, Singapore 639798
}

\begin{abstract}
Inspired by the success and informed by the principles of the Extensive Reading (ER) approach, Extensive Listening (EL) and Viewing have started to gain the attention of both L2 researchers and practitioners. The purpose of this paper is to examine the theoretical and research base of EL and the extent to which it is similar to or different from ER, discuss its language learning benefits for L2 students in different learning contexts, and explore different ways EL can be productively implemented in the classroom. Practical suggestions on how to source for freely available EL materials on the Internet and how these can be pedagogically used to enhance language proficiency are also offered. We believe that EL, when systematically implemented, can not only enhance students' listening skills but also have a positive influence on the students' overall language development.
\end{abstract}

Keywords: extensive listening, extensive viewing, extensive reading, extensive listening materials and activities, input theory

DOI: http://dx.doi.org/10.15639/teflinjournal.v30i2/237-256

In English as a Foreign Language (EFL) contexts, Extensive Listening (EL) is defined as a language teaching and learning approach that encourages language learners to be exposed to a large amount of easily comprehensible and enjoyable materials presented in the target language over an extended period. In a more general sense, Rixon (1986) defines it as listening for pleasure without paying attention to the specific content or language being used. 
According to Waring (2008), EL is a way of improving listening fluency by practicing listening to easy texts. Because many of the characteristics of EL resemble those of Extensive Reading (ER), EL is considered the oral equivalent of or the sister of ER (Lynch, 2009; Waring, 2011). Mayora (2017) adapts five general principles of ER that could be applied to EL - quantity, comprehensibility, learner-centeredness, meaning-orientation, and accountability. Based on these principles, learners are encouraged to listen to large amounts of easy target language texts within or just above their current comprehension and linguistic level, select the texts based on the potential relevance, interest, and enjoyment instead of for their linguistic content, perform comprehension-oriented, non-intrusive tasks such as "listening cards," writing or telling an appreciation, the main idea or a summary in their native language of the material at their own pace without intervention from the teacher, and focus on meaning rather than form.

The emergence of EL is prompted by the success of the ER approach that promotes learning by doing. According to ER scholars, reading skills are best learned through frequent reading, so listening skills, too, could best be developed through frequent listening. However, EL has not been researched and implemented as widely as ER has. In fact, only a few EL studies have been conducted within the EFL context. Moreover, not many books on teaching listening include simple descriptions, explanations and examples on EL and how it is implemented in different EFL settings. Hence, misinterpretation is inevitable. EL in L2 context is still in its early stage and form. This article aims to contribute to the development of EL in L2 contexts, especially in Indonesia, by reviewing its history, explaining its basic concepts, examining its current implementation in Indonesia and discussing its potentials in the Indonesian context.

\section{BRIEF HISTORY OF EXTENSIVE LISTENING/VIEWING}

Inspired by the success of the ER approach in improving reading skills and motivation and challenged by the unsatisfactory results of the comprehension as well as the strategy training approach to teaching listening, a number of English Language Teaching (ELT) scholars has been advancing the implementation of EL as classroom and out of the classroom activities. EL has been developed based on the characteristics of ER. Initially, reading-whilelistening using graded reader audiobooks is listed as one of the useful ER 
activities language learners can do to improve their reading fluency (Waring, personal website, n.d.). Waring (2008) extends reading-while-listening as one type of EL activities. In his short paper entitled Starting Extensive Listening, he explains what EL is, how EL materials should be chosen, what materials can be used in EL programs, how EL materials can be adjusted to fit learner comprehension level, as well as how listening circle is used for sharing and discussing EL materials. Because proponents of EL have also been working in the area of ER, early works on EL mirror ER works.

Although most of the characteristics of ER and EL are similar, EL has unique features that differentiate it from ER because in many ways, listening is different from reading. Renandya and Farrell (2011) identify some aspects that distinguish the two, i.e., listening is fast, variable, with blurry word boundaries that need to be processed in real time. To be able to listen comfortably in L2, learners need to possess automaticity and fluency. Unlike listening which is an online activity, reading is an offline one. Learners can read word by word at their own pace or go back to any parts that they need. But doing this in real-life listening is not always possible. Learners can ask for repetitions and clarifications or ask the interlocutors to slow down the speech, but it is distressing to listen to a speech which is fast and with unclear word boundaries. Learners often find the words in connected speech confusing. Even though spoken language is syntactically simpler than written language, Chang (2012) highlights that it contains substantially more incomplete sentences and shorter idea units, includes various disfluencies and self-corrections as well as more colloquial expressions, involves face-to-face interactions, influences by stress, intonation, pitch, and volume, as well as accents and background noise, and occurs in real time. Consequently, spoken words may be misinterpreted during listening. Recent works on EL have taken into account the unique characteristics of listening and spoken language by integrating listening with other skills or learning techniques to make it more doable and fruitful. In recent years, discussions on EL include viewing as one of its variety of activities. The viewing activity and its variants make the listening experience more diverse and authentic (Renandya \& Jacobs, 2016) and help learners comprehend spoken language better because they receive input from more than one mode.

Initially, EL studies and programs rely heavily on the use of audiobooks available as graded reader supplements. Many studies focus on the use of this type of audio materials because they are obtainable commercially, systematically graded, and available in wide varieties of topics. However, they 
usually feature one flawless speaker in every audiobook, so they lack in authentic cues and discourse markers of spoken language. Commercial audiobooks cannot be duplicated due to their copyrights. Moreover, listening to audiobooks is time-consuming and boring because it takes a long time to improve comprehension and vocabulary levels (Apple, 2006). In its further development, EL has incorporated the use of a variety of non-commercial audio and video materials available on the Internet. The use of authentic materials in the form of podcasts, movies, TV and radio programs, videos and other Internet resources, is highly suggested in EL.

\section{BENEFITS OF EXTENSIVE LISTENING/VIEWING}

The benefits of EL have been well acknowledged in the literature. First, EL is motivating because learners listen to materials that they want to listen to and those they can understand and enjoy. It provides learners with a lot of comprehension practice in the target language (Renandya 2012; Waring, 2008) that allows them to enjoy listening, focus on understanding and interacting with the text (Waring, 2008), and experience a high level of language comprehension (Renandya, 2011). By using easy or very easy texts, focusing on narrow topics at a time, and receiving multimodal input, learners are given the chance to comprehend the aural texts better because they understand most of the vocabulary and grammar in the text, repeatedly listen to words used within the narrow topics, and relate the spoken and written forms of words presented simultaneously. Additionally, learners are more involved and motivated because they have the opportunity to select their own materials. Comprehensible and interesting EL materials motivate learners to keep on listening in the target language.

Second, EL develops listening fluency and automaticity in recognising spoken texts. It builds learners' confidence and ability to deal with normal speech rate (Renandya, 2012), recognise spoken words and to chunk for better comprehension (Renandya, 2011; Waring, 2008), as well as improve fluency by building listening speed (Chang, 2012; Waring, 2008). Because learners practice listening to aural texts within their level of proficiency for an extended period, they become familiar with the words used in various narrow topics and contexts. Learners do not need to stop and replay the texts to understand them. The frequent and repeated practice helps them become more fluent listeners. 
As learners are more relaxed in EL, their confidence in listening to texts in the target language also increases.

Third, EL improves listening comprehension primarily because it enables learners to process spoken language more accurately and fluently (Renandya, 2012). It improves comprehension and listening skills (Brown, Waring, \& Donkaewbua, 2008; Chang, 2010), especially when it is conducted using multimodal input, such as in reading while listening, listening and viewing, and listening while viewing and reading activities. Yonezawa and Ware (2008) observe that learners find the combinations of EL and active listening techniques, such as shadowing, improve their listening skills. EL in the form of reading while listening also improves pronunciation (Vo, 2013), vocabulary acquisition, and vocabulary retention (Brown, Waring, \& Donkaewbua, 2008).

Fourth, EL is flexible because it can be implemented in the classroom as well as out of the class. It comes with flexibility in terms of where and when it can be done (Antle, 2010). Learners can engage in EL a few minutes before classes start, during breaks, while waiting or walking, or in the comfort of their own home.

Fifth, EL improves learning independence. It fosters autonomy in listening (Chang, 2012) because learners can choose the learning materials by themselves and monitor the process and progress of their own learning. Learners also have control over what, when and how they listen to the aural texts. Altogether, the activities cultivate independent learning habits useful for lifelong learning. Learners are empowered as they decide their goals, choose their own materials, and evaluate the effectiveness of their own learning. They are then in a better position to initiate learning based on their personal needs, priorities, and preferences. Besides, EL practice can develop students' metacognitive skills for language learning (Vandergrift \& Goh, 2012).

Last, but not least, EL emphasises the practice of all language skills that can reinforce the use of L2 in real life (Yeldham, 2016). EL activities vary from listening only, reading while listening, listening and viewing, to listening while viewing and reading. These varieties allow learners to adjust their learning activities to the type of text, their comprehension needs, and the level of comprehensibility of the texts. Moreover, learners also do other undemanding tasks that enable them to make the aural texts and the listening experience more personal and engaging. 


\section{WHY HAS EXTENSIVE LISTENING/VIEWING NOT BEEN ADOPTED WIDELY?}

Although EL has been around for more than one and a half decades, the approach has not been enthusiastically adopted by language teachers. This may occur due to the fact that EL has not been extensively researched nor publicised. Its concept is not familiar to many practitioners. Besides, not until recently, easy and easier EL materials are readily available, especially for beginners and low intermediate learners. In EL, learners need to practice comprehending what they listen (Ridgway, 2000), so they need easily comprehensible materials. When they listen to materials which are too difficult, they become discouraged and stop listening. Furthermore, EL requires a large number of materials that can be used over a long period. Often teachers and learners do not know where to find appropriate materials, how to choose them, or how to adapt them for EL purposes.

It takes time for EL to show its contributions to learners' proficiency development. Learners need to spend lots of time over an extended period for listening to a large amount of comprehensible and enjoyable listening material (Mayora, 2017; Renandya \& Jacobs, 2016; Waring, 2008). Yeldham (2016, p. 36), for example, maintains that EL " $[\ldots]$ is also based on implicit learning, which may require considerable time for many learners to develop their listening." Thus, EL may not suit language learning contexts that require immediate results in a limited timeframe, a common condition of most EFL learning contexts.

EL is too often seen as unstructured out of the class activities that learners have to do by themselves without the support of others. This type of activity is often seen as inefficient because it leaves learning too much to chance for some learners (Vandergrift \& Goh, 2012). On top of that, teachers are not sure of their roles in an EL program as learners are encouraged to take most of the initiatives (Yonezawa \& Ware, 2008). When learners are left to their own devices to learn L2, some may survive, but others may not. The long process of exercising EL may discourage most learners because they cannot see the immediate results of their efforts. Therefore, support from teachers as well as other learners is needed. Learners also need to learn how to motivate themselves, to control and monitor their progress and to keep on practicing listening. 
Ivone \& Renandya, Extensive Listening and Viewing in ELT 243

\section{CHARACTERISTICS OF EXTENSIVE LISTENING/VIEWING}

When talking about a language learning approach such as EL, we often ask the following questions: what sort of process do learners have to go through? Also, what results should they expect? To answer these questions, we need to know the aims, materials, activities, and assessment of EL.

\section{Aims}

The five main purposes of conducting EL are:

- exposing learners to vast amount of comprehensible spoken texts over an extended time that in the long run contributes to the development of their comprehension and listening skills,

- providing fun and enjoyable listening experience by allowing learners to listen to topics of their interests,

- developing general comprehension of spoken texts by encouraging learners to listen for meaning instead of focusing on form,

- developing listening fluency and automaticity by improving the speed of recognition of language elements such as sounds, words, and phrases and grammar while listening to a text so that learners can comfortably listen to texts spoken at normal speed, and

- improving motivation and confidence in listening in the target language by making the listening experience fun and doable.

\section{Materials}

The advancement of technology and the Internet facilitates the provision of a vast range of EL materials. Learners have the options of using audio, audiovisual, and multimedia materials in EL. According to Holden III (2008, p. 309), EL materials can take the forms of "audiobooks, storytelling websites, spoken word and news websites, interviews, videotapes, TV, Youtube.com, movies and dramas, academic lectures, speeches, and virtually any type of music that has comprehensible lyrics." Today, many of these materials are accessible, downloadable, and sharable over the Internet. Due to their digital format, they are also easily modified and adapted in terms of content, speed, as well as presentation. Content can be taken in part or in full as well as blended with other materials of the same or different forms. Learners can adjust the 
speed of the materials to suit their level of comprehension. Materials can also be presented in various forms, such as aural, visual and textual.

The most commonly used auditory mode material is the audiobooks available as the supplement of graded readers. These audiobooks are designed for language learning, but most of them are not free. Some websites such as Lit2Go (https://etc.usf.edu/lit2go/) and Readworks (www.readworks.org/) provide graded reader audiobooks free of charge; however, they are not developed for ELT learners. Every graded reader audiobook series has its own grading and labelling system. Some of the systems are convertible to the Common European Framework of Reference (CEFR) for languages. For example, the Macmillan Readers label their materials with Starter and Beginner, Elementary, Pre-Intermediate and Upper-Intermediate levels which are equivalent to A1 to B2 CEFR levels. Other graded readers and audiobooks, such as Lit2Go and Readworks, use the United States Grade Level standard of K-12 because the materials made available on these websites are designed for native speakers of English in the US. Because they are graded, learners can easily find materials within or below their proficiency level and to proceed to a higher level whenever they are ready to do so.

In addition to audiobooks, podcasts are often used as auditory EL materials (Alm, 2013; Cross, 2014). A podcast is "a multimedia file distributed over the internet using syndication feeds, for playback on mobile devices and personal computers" (Kidd \& Chen, 2009, p. 364). Podcasts on diverse interesting topics are accessible from many major news websites, such as CNN, BBC, PBS, NPR, Time Magazine, USA Today, and VOA as well as podcast providers, such as https://www.betteratenglish.com/; https://podcastalley.com/; https://thepodcastnetwork.com/; www.podcastsinenglish.com; and www.bbc.co.uk/programmes/p02pc9zn. According to Cross (2014), podcasts can be authentic (developed not for language learning purposes), semiauthentic (modified from authentic texts for language learning purposes) or non-authentic (developed as language learning resources), graded or not graded. Language learning website such as LiteracyNet (http://iteracynet.org/learningresources/) has lots of authentic and semiauthentic texts on the website.

Some other potential materials for EL are all types of videos available on the Internet. Fictions, non-fictions, movies, tutorials, talks, documentaries, videocasts, serials, news and current affairs, TV shows, and video clips are abundantly available on youtube.com, videojug.com and video.google.com. 
Ivone \& Renandya, Extensive Listening and Viewing in ELT 245

There are also inspiring and informative talks available on www.ted.com/talks. The following sample websites offer audio and audiovisual resources for various proficiency levels many practitioners found useful for EL activities.

- BBC Learning English (http://www.bbc.co.uk/worldservice/learningenglish/multimedia/).

- Breaking News English (www.breakingnewsenglish.com)

- British Council LearnEnglish (https://learnenglish.britishcouncil.org/apps/learnenglish-podcasts)

- ELLLO/English Listening Lesson Library Online (http://www.elllo.org),

- ER-Central (https://www.er-central.com)

- Englishclub (http://www.englishclub.com/listening),

- ESL Podcasts (http://a4esl.org/podcasts/),

- ESL-bits (www.esl-bits.net),

- ESL-Lab (www.esl-lab.com),

- ManyThings.org (http://www.manythings.org/b/e/).

- Real English (www.real-english.com).

- Spotlight Radio (http://www.spotlightradio.net/listen/),

- Storyline Online (http://www.storylineonline.net/).

- Teacher Tube (www.teachertube.com),

- To Learn English (www.tolearnenglish.com),

- Voice of America Special English (http://wwwl.voanews.com/learningenglish/home/).

Several researchers suggest the use of graded reader audiobooks in EL because they have rich collection of texts that provide comprehensible input, especially for lower proficiency listeners. Van Zeeland and Schmitt (2013) confirm that $95 \%-98 \%$ lexical coverage is sufficient for learners to reach an adequate comprehension of spoken input. To be able to listen comfortably in the target language, therefore, learners need to know at least $95 \%$ of the vocabulary used in the text. Graded reader audiobooks are created based on vocabulary coverage standards so their levels can be matched to learners' comprehension levels. However, graded reader audiobooks may be perceived as lacking in authenticity because they present mostly monologues of a single speaker with impeccable speech.

Quite the reverse, resources available on the Internet are often authentic and ungraded. Practitioners have used authentic materials such as news broadcasts, podcasts, and feature films in EL with positive outcomes. This type 
of materials exposes learners to spoken language in a more natural setting and contains rich conversational features in the forms of repetition, rephrasing, and connected speech (Field, 2000). They also offer learners rich insights into the target language culture and many varieties of aural texts that give them more options in choosing their listening materials (Alm, 2013). Authentic materials can be made more comprehensible using subtitles and captioning, giving learners the chance to read while listening. Hence, learners can use authentic materials for EL purposes providing that they not be too difficult to listen to or are accompanied by written texts (e.g., scripts, subtitles, and captions) or illustrations (pictures, photos, comics, animation, etc.) that make them more comprehensible. There are no rules as for when to use authentic materials. Holden III (2008) suggests balancing learners' proficiency levels, interests, and needs. Beginners can focus more on structured or scripted materials such as graded reader audiobooks and other graded materials. They can gradually increase the use of authentic materials as they progress to intermediate and advanced levels.

Materials that allow learners to do series listening or viewing such as TV or radio series are suitable for EL as they can be used in narrow listening or viewing. In narrow listening or viewing, learners are exposed to repeated use of similar language that leads to more profound comprehension of aural texts, improvement in listening skills, and vocabulary acquisition (Renandya, 2012). According to van Zeeland and Schmitt (2013), a great deal more than 15 exposure is needed for learning vocabulary from listening. The repeated exposure to words, expressions, and phrases is likely to occur when learners conduct narrow listening or viewing, making it more possible for learners to acquire the vocabulary. Thus, TV and radio series are good for narrow listening or viewing because they present texts of the same genre and contain words and expressions that reoccur throughout the episodes.

\section{Activities}

EL activities do not merely involve listening and the use of exclusively aural input. Ideally, learners listen to comprehensible and enjoyable texts that fit their proficiency and comprehension level as well as their interests. However, sometimes the available materials are too difficult for their level and should be made more comprehensible by providing additional textual or visual input. Some aural texts presented in the form of news and movies are 
interesting because they are presented in audiovisual mode and sometimes with captions or subtitles. It is, therefore, possible that learners are engaged in some viewing and reading activities during listening. Overall, there are five types of listening activities learners can perform during EL - listening only, shadowing/ overlapping while listening (active listening), reading while listening, listening and viewing, and combined listening, viewing and reading activities.

\section{1) Listening Only}

During a listening only activity, learners listen and enjoy the aural text. They may even do it as a background activity of when they jog, drive, or cook. This type of listening may be too demanding for beginners and low intermediate learners; thus, it is essential that the texts used are easy or very easy. Listening only can be conducted in class using teacher-directed dictations and read-alouds or outside the classroom in the form of self-directed listening for pleasure (Renandya \& Farrell, 2011).

\section{2) Active Listening (Shadowing/Overlapping while Listening)}

Listening may involve active listening techniques, such as shadowing and overlapping, which are useful for improving fluency, correcting pronunciation errors, and automatising the recognition of spoken words or chunks of language. "Overlapping is reading aloud using the text or script while listening. [...] Shadowing is reproducing phrases right after listening to a chunk of meaningful English without looking at the text" (Yonezawa \& Ware, 2008, p.1256). Both shadowing and overlapping can be performed silently or by vocalising the texts. The activities that require learners to listen to a text and vocalise it as accurately as possible mainly facilitate bottom-up listening because it leaves little or no time to spare for accessing meaning (Hamada 2016). Learners should be encouraged to use texts with native speakers' voice when they conduct active listening activities so that they have access to a better model of spoken language.

\section{3) Reading while Listening}

Sometimes texts are available in both aural and textual formats - for instance, songs and song lyrics, podcasts and audio scripts, and graded readers and audiobooks. When learners have access to both forms, they can read the texts while listening to the aural texts whenever they need to make the aural texts more comprehensible, improve their vocabulary, focus on the 
pronunciation, stress or intonation of spoken language, and draw the connection between spoken and written words and expressions. The literature suggests that reading while listening makes aural texts more comprehensible and exciting, promotes vocabulary development, and helps learners concentrate on listening to the texts better. Moreover, it may have stronger and long-lasting effects on the development of listening competence and acquisition of some linguistic elements (Renandya, 2012). However, reading while listening may only have temporary comprehension benefits and encourage learners to be overdependent on written text, a type of scaffolding that often does not exist in real-life listening (Yeldham, 2016).

\section{4) Listening and Viewing}

A lot of L2 materials are in the form of audiovisual texts or videos. Learners often find videos more comprehensible than audio recordings because they include aural and visual input as well as nonverbal clues that facilitate the processing of spoken input. The literature suggests that watching audiovisual programs is useful for developing autonomous listening strategies as well as listening and speaking fluency. In conducting EL, learners have the options of using serials or random videos. When watching serials, learners conduct narrow viewing that involves watching different episodes of the same program in chronological order. Through the activity they gradually develop background knowledge of the characters and their relationships, the setting, and the storyline that can help them comprehend the story easier and better. Besides, watching serials is easier because the lexical load of the episodes of the same program is lower than that of unconnected programs (Rodgers \& Webb, 2011).

\section{5) Combined Listening, Viewing, and Reading}

The activity is a variant of the listening and viewing activity. The benefits of performing combined listening, viewing and reading are better comprehension and vocabulary improvement. Learners find the combined listening, viewing and reading captions useful, particularly when watching TV programs which are considered difficult for their level of proficiency (Webb, 2015). Watching a video with captions also results in more vocabulary learning than watching an audio-only video (Perez, van den Noortgate, \& Desmet, 2013), especially among intermediate and low-proficiency EFL learners (Peters, Heynen, \& Puimege, 2016). 
Ivone \& Renandya, Extensive Listening and Viewing in ELT 249

\section{Assessment}

The assessment methods used in EL reflect the aims of the approach and thus performed not only as a strategy of planning, assessing, reflecting and monitoring learning progress and results, but also a way of maintaining learners' responsibility. One of the most commonly used assessment methods in EL is listening journal/diary/log. Journals are useful for recording EL activities as well as learners' reflection on their listening experience. The use of listening journals in EL promotes listening autonomy as they are used to guide learners in planning, monitoring and evaluating their listening activities (Chen, 2017). Listening journals usually document details of the listeners (e.g. name, class, etc.), the texts (e.g. title, length, source, etc.), and the EL activities (e.g. date, length, etc.), as well as some post-listening tasks, such as summary and listeners' opinion of the texts, a reflection of the listening activity, and planning for further listening. For less self-regulated learners, structured listening journal templates can be used so that they are well guided in the writing of the journals. Alternatively, open-ended prompts can provide pointers of what learners should include in their journals.

Another type of EL assessment involves interesting tasks which are used to show that learners have responsibly completed the EL activities. The tasks can be in the form of "comprehension-oriented, non-intrusive tasks" (Mayora, 2017 , p.102), such as writing or telling an appreciation, stating the main idea or making a summary of the aural texts in L1 or L2, or more authentic tasks that reflect real-life listening tasks such as dictation, stimulus-response, note-taking, editing and retelling.

\section{EL IN INDONESIA}

EL has caught the eye of Indonesian EFL practitioners researching and working in the area of teaching listening. The eight articles on EL published in conference proceedings and academic journals in the past five years (five of which were published in 2018) and one unpublished Masters' thesis on EL reviewed in this section give us a glimpse of how EL is viewed, researched, and implemented in Indonesia. The findings of the studies corroborate those of previous EL studies in that learners find EL activities useful for improving motivation, listening skills, vocabulary, and learning autonomy. 
Two of the studies are on the implementation of EL in secondary school level. Al-Baekani and Ridwan (2018) conducted a descriptive study on the process of listening activity in the classroom using mobile phones as interactive media in EL. They also asked for the students' opinions on the learning experience. The classroom observations showed that mobile phones were mostly used for 25 minutes during the main teaching and learning activities which were followed by a listening comprehension test. Although the researchers concluded that the students responded positively to the use of mobile phones in EL, the analysis of the questionnaire data showed low percentages of the frequency of answers. In another study, Mahmudah (2015) investigated the effect of exposure to spoken English to the students' listening skills. The study also examined the students' attitudes towards listening activities in general and the implementation of EL. The participants were two classes of eleventh graders in a school in Bandung Barat. The findings of the quasi-experimental study showed that EL could significantly improve the students' listening skills. Moreover, they also responded positively to the implementation of EL even though some thought that the listening materials were too difficult. There are some major flaws in the methodology that influence the quality of the data analysis, findings, and conclusions of both studies; however, it can be seen that English language teachers at the senior secondary level have started to see EL as a sound alternative in teaching listening.

At the tertiary education level, especially in English departments, EL has received a warmer welcome. In fact, all of the EL studies conducted at this level are situated in undergraduate English departments. Astika (2015) shared the design and development of an EL course offered at the English Education Program in a private university in Central Java. The course was designed based on a model of curriculum development which involves needs analysis, objectives, testing, materials, and teaching. His paper presents a brief description of the course syllabus, sources of materials, students' journals, their presentations, and comments they wrote about the course.

There are three action research that successfully implemented EL for the purpose of motivating learners to practice listening in the target by using authentic materials from the Internet (Hapsari \& Ratri, 2014; Saputra, 2018; Saputra \& Fatimah, 2018) and from other sources, i.e., CDs and books (Hapsari \& Ratri, 2014) and for improving their listening skills. Hapsari and Ratri (2014) implemented EL in one listening course class at an undergraduate level. 
Thirty-five English department students participated in this one-semester-long study. For the first few meetings, the lecturer selected the authentic materials to be listened to and the learning activities to be conducted in class. Later, the students worked in groups of three to choose the materials, design the learning activities, and teach using the materials and activities in class for thirty minutes. At the end of their teaching, each group received feedback from the class and the lecturer on whether or not their objectives have been achieved. The researchers believed that the whole sequences of experience gave the students the opportunity to explore authentic materials, perform repeated listening, and evaluate their performance.

In another study, Saputra and Fatimah (2018) utilised TED and YouTube materials in an EL course for first-year English department students. The students in the study shared that Youtube and TED materials enriched their English vocabulary and that the listening tasks created a more dynamic and less monotonous learning atmosphere. In a similar study involving fourth-semester students, Saputra (2018) reported similar results. He wanted to change his students' perceptions in learning listening through Youtube online video and the implementation of ICT in the EFL classroom. In the study, the students were required to do some activities - listen, note take, discuss and download materials as homework. The results showed changes in the students' perception. Overall, the students found performing EL using YouTube materials amazing. It helped them increase their vocabulary and acquire new information.

Two descriptive studies looked into the implementation of EL in blended learning context (Widodo \& Rozak, 2016) and the choice of materials used in out of the classroom EL activities (Wahidah \& Luthfiyyah, 2018). Widodo and Rozak (2016) examined the quantity and pattern of engagement of the students in a collaborative and reflective online video-assisted EL practice over a period of 12 weeks. The 24 students participated in four main activities - selfselection of EL materials, collaborative video viewing, reflective practice, and online discussion. The findings suggest that from the EL experience, the students learned to listen for meaning and to become autonomous and reflective language learners. In another descriptive study, Wahidah and Luthfiyyah (2018) examined learners' choice of EL materials that they selected from the links given by the lecturers. Thirty-nine students who took the listening course in the fourth semester only accessed Youtube and used songs and movies as the materials in their listening activities. Their most favourite 
materials were songs. On average, they listened to songs five times a week with the duration of four minutes for each listening activity.

Setyowati and Kuswahono (2018) conducted an experimental study on the impact of the use of extensive listening in developing the listening skills of a group of 10 English department students. Throughout the project, the students participated in EL activities and group discussion. Statistical analysis of the pre- and post-test showed that EL activities give significant impact on the students' listening proficiency skill. The findings indicated that extensive listening does not only enhance students' listening proficiency but also increase their motivation to keep being active in listening class.

Most of the EL studies reviewed in this section do not put much emphasis on the key features of EL which is the actual listening and viewing in the target language. Instead, they focus on the use of authentic materials, especially those found on the Internet and in the forms of songs and movies. Students in one of the studies reported that some of the materials were too difficult for their level. Although authentic materials can be interesting, care needs to be taken that students listen to and view those that are within their level. In other words, the materials have to be comprehensible. Others are tempted to include reflective components and other metacognitively informed tasks and activities that may take learners' attention and time away from the actual listening and viewing that they need to do. It should be kept in mind that EL means students doing a lot of listening and viewing. In the end, it is the quantity of listening and viewing that results in language improvement. Not the reflection, not the collaborative work, not the extra tasks, etc. Many of the studies will also benefit from the employment of better research methodology; however, they convey the impression that EL is viewed as a potential approach to be implemented at higher education level, especially within the English department programs. More applicable models of EL implementation are needed at the lower education levels because of the time constraint and scope of materials that should be covered at these levels.

\section{CONCLUDING REMARK}

The literature often reminds researchers and practitioners that there is no one best teaching and learning approach, method, or technique that suits every learner throughout the course of their language learning experience. This is because language learning is a dynamic learning process. The more crucial task 
for language teachers and learners is actually to find the more suitable context and manner for implementing an approach, method, and technique. This applies to the teaching of listening which is problematic due to the many factors that contribute to the difficulties in EFL listening. Various instructional approaches have been implemented with a varying degree of results. However, many still ask for an instant way of producing excellent results. What we need is to learn from those who have succeeded in learning English. Successful listeners do not only conduct intensive listening and rely on classroom learning for their success. Language learning needs exposure to a vast amount of target language. It needs repetition. It requires hard work and motivation. Researchers and practitioners have highlighted the potential use of EL in addressing these issues and many more.

\section{REFERENCES}

Al-Baekani, A., \& Ridwan, I. (2018). Integrated of mobile phone as interactive media in extensive listening. Proceedings of SHS Web of Conferences, 42, 00006. Retrieved from https://www.shs-conferences.org/articles/shsconf/ abs/2018/03/shsconf_gctale2018_00006/shsconf_gctale2018_00006.html

Alm, A. (2013). Extensive listening 2.0 with foreign language podcasts. Innovation in Language Learning and Teaching, 7(3), 266-280.

Antle, J. B. (2011). Extensive Listening and how it affects reading speed. The Language Teacher 35(5), 3-5.

Apple, M. (2006). Developing autonomous habits with extensive listening. In E. M. Skier \& M. Kohyama (Eds.), More autonomy you ask! (pp. 33-47). Tokyo: Learner Development SIG, JALT.

Astika, G. (2015). Extensive listening: Design and its implementation. The $62^{\text {nd }}$ TEFLIN International Conference Proceedings: Teaching and Assessing L2 Learners in the $21^{\text {st }}$ Century. Denpasar: Universitas Udayana.

Brown, R., Waring, R., \& Donkaewbua, S. (2008) Incidental vocabulary acquisition from reading, reading-while-listening, and listening to stories. Reading in a Foreign Language, 20(2),136-63.

Chang, C. -S. A. (2012). Gains to L2 Learners from extensive listening: Listening development, vocabulary acquisition and perceptions of the intervention. Hong Kong Journal of Applied Linguistics, 14(1), 25-47. 
Chang, C.-S. (2010). Second-language listening anxiety before and after a 1-yr. intervention in extensive listening compared with standard foreign language instruction. Perceptual and Motor Skills, 110(2), 355-65.

Chen, C.W.Y. (2017). Guided listening with listening journals and curated materials: a metacognitive approach. Innovation in Language Learning and Teaching, 13(2), 133-146.

Cross, J. (2014). Promoting autonomous listening to podcasts: A case study. Language Teaching Research, 18(1), 8-32.

Dupuy, B.C. (1999). Narrow listening: An alternative way to develop and enhance listening comprehension in students of French as a foreign language. System, 27(3), 351-361.

Field, J. (2000). Not waving but drowning: A reply to Tony Ridgway. ELT Journal, 54(2), 186-195.

Hamada, Y. (2016). Shadowing: Who benefits and how? Uncovering a booming EFL teaching technique for listening comprehension. Language Teaching Research, 20(1), 35-52.

Hapsari, H., \& Ratri, D.P. (2014). Extensive listening: Let students experience learning by optimizing the use of authentic materials. Bahasa \& Sastra, 14(2), 251-261.

Holden III, W. R. (2008). Extensive listening: A new approach to an old problem. Journal of the Faculty of Humanities, University of Toyama, 49, 299-312.

Kidd, T. T., \& Chen, I. L. (2009). Wired for learning: An educator's guide to web 2.0. Charlotte, NC: Information Age Publishing.

Lynch, T. (2009). Teaching second language listening: A guide to evaluating, adapting, and creating tasks for listening in the language classroom. Oxford, UK: Oxford University Press.

Mahmudah, M. (2015) The implementation of extensive listening and its effect on the students' listening skill (Master's Thesis, Universitas Pendidikan Indonesia, Bandung, Indonesia)

Mayora, C. A. (2017). Extensive listening in a Colombian university: Process, product, and perceptions. HOW, 24(1), 101-121.

Perez, M. M., van den Noortgate, W., \& Desmet, P. (2013). Captioned video for L2 listening and vocabulary learning: A meta-analysis. System, 41, 720-39. 
Peters, E., Heynen, E., \& Puimege, E. (2016). Learning vocabulary through audiovisual input: The differential effect of L1 subtitles and captions. System, 63, 134-148.

Renandya, W. A., \& Farrell, T. (2011). Teacher, the tape is too fast! Extensive listening in ELT. ELT Journal, 65(1): 52-59..

Renandya, W. A. (2011). Extensive listening in the second language classroom. In H. P. Widodo \& A. Cirocki (Eds.), Innovation and Creativity in ELT Methodology (pp. 28-41). New York: Nova Science Publishers.

Renandya, W. A. (2012). The tape is too fast. Modern English Teacher, 21(3), 5-9.

Renandya, W. A., \& Jacobs, G. M. (2016). Extensive reading and listening in the L2 classroom. In W. A. Renandya \& H. P. Widodo (Eds.), English Language Teaching Today (pp. 97-110). New York: Routledge.

Ridgway, T. (2000). Listening strategies: I beg your pardon? ELT Journal, $54(2), 179-185$.

Rixon, S. (1986). Developing listening skills. London: Macmillan.

Rodgers, M.P., \& Webb, S. (2011). Narrow viewing: The vocabulary in related television programs. TESOL Quarterly, 45(4), 689-717.

Saputra, Y. (2018). Changing students' perception on learning extensive listening through Youtube. English Empower, 3(1), 41-49.

Saputra, Y., \& Fatimah, A. S. (2018). The use of TED and YOUTUBE in extensive listening course: Exploring possibilities of autonomy learning. Indonesian Journal of English Language Teaching, 13(1), 73-84.

Setyowati, Y., \& Kuswahono, D. (2018). The effect of extensive listening with "Ted Ed Video" to promote students' proficiency in listening. The 1st International Conference on Education Language and Literature (ICONELITE) 2018 Proceeding, 1(1), 261-264.

van Zeeland, H., \& Schmitt, N. (2013). Incidental vocabulary acquisition through L2 listening: A dimensions approach. System, 41, 609-624.

Vandergrift, L., \& Goh, C. M. (2012). Teaching and learning second language listening. New York: Routledge.

Vo, Y. (2013). Developing extensive listening for EFL learners using Internet resources. Hawaii Pacific University TESOL Working Paper Series, 11, 29-51.

Wahidah, F. S., \& Luthfiyyah, R. (2018). Extensive listening activities of EFL learners in higher level of education. Academic Journal PERSPECTIVE: Language, Education and Literature, 6(2), 119-125. 
Waring, R. (2008). Starting an extensive listening program. Extensive Reading in Japan: The Journal of the JALT Extensive Reading Special Interest Group, 1(1) 7-9.

Waring, R. (2011). Extensive Reading in English Teaching. In Widodo, H. \& A. Cirocki (Eds.) Innovation and Creativity in ELT Methodology (pp. 6980). Nova Publishers: New York.

Waring, R. (n.d.). Starting extensive listening. Retrieved from http://www.robwaring.org/er/ER_info/starting_extensive_listening.htm.

Webb, S. (2015). Extensive viewing: Language learning through watching television. In D. Nunan., \& J. C. Richards (Eds.), Language Learning Beyond the Classroom (pp. 159-168). New York/London: Routledge.

Widodo, H.P., \& Rozak, R.R. (2016). Engaging Student Teachers in Collaborative and Reflective Online Video-Assisted Extensive Listening in an Indonesian Initial Teacher Education (ITE) Context. Electronic Journal of Foreign Language Teaching, 13(2), 229-244.

Yeldham, M. (2016). Approaches to L2 Listening Instruction. The European Journal of Applied Linguistics and TEFL, 5(2), 31-42.

Yonezawa, M., \& Ware, J.L. (2008). Examining extensive listening. In K. Bradford-Watts, T. Muller, \& M. Swanson (Eds.), JALT2007 Conference Proceedings. Tokyo: JALT. 